Emir. J. Food Agric. 2008.20 (2):18-27

http://www.cfa.uaeu.ac.ae/research/ejfa.htm

\title{
The effect of dietary inclusion of halophyte Distichlis grass hay Distichlis spicata (L.) on growth performance and body composition of Emirati goats
}

\author{
S. A. Al-Shorepy and G. A. Alhadrami \\ Department of Aridland Agriculture, College of Food and Agriculture, U.A.E. University, \\ Al Ain, P.O. Box 17555, U.A.E.
}

\begin{abstract}
Forty four Emirati goat kids were used in a feeding trial to study the effect of feeding diets containing various level of halophyte Distichlis grass hay on growth, feed and water intakes and body composition. Animals were randomly allocated to four dietary treatment groups, which were initially formulated to have $100 \%, 66.7 \%, 33.3 \%$ or $0.0 \%$ Distichlis grass hay as a source of forage. The kids receiving 0.0 Distichlis grass hay $(100 \%$ Rhodes grass hay) served as the control. Feed and water were offered ad libitum. Male kids were slaughtered at the end of feeding trials. The average daily feed intake was significantly $(\mathrm{P}<0.05)$ higher for the animals fed the diet with $100 \%$ Distichlis grass hay than those animals fed the diet with $0.0 \%$ Distichlis grass hay $(100 \%$ Rhodes grass hay). The feed conversion ratio (FCR), i.e., $\mathrm{kg}$ feed $/ \mathrm{kg} \mathrm{BW}$, improved $(\mathrm{P}<0.05)$ by feeding a high level of Distichlis grass hay. The goats fed a diet with $100 \%$ Distichlis grass hay had a heavier $(\mathrm{P}<0.05)$ carcass weight and higher $(\mathrm{P}<0.05)$ dressing percentage but lower $(\mathrm{P}<$ 0.05 ) intestine-content than the kids fed a diet with $0.0 \%$ Distichlis grass hay. The average proportions of non-carcass components were not affected by the treatment diets. This study indicated that Distichlis grass hay has better potential for feeding goats than Rhodes grass hay.
\end{abstract}

Keywords: Distichlis grass hay, growth performance, body composition, Emirati goats.

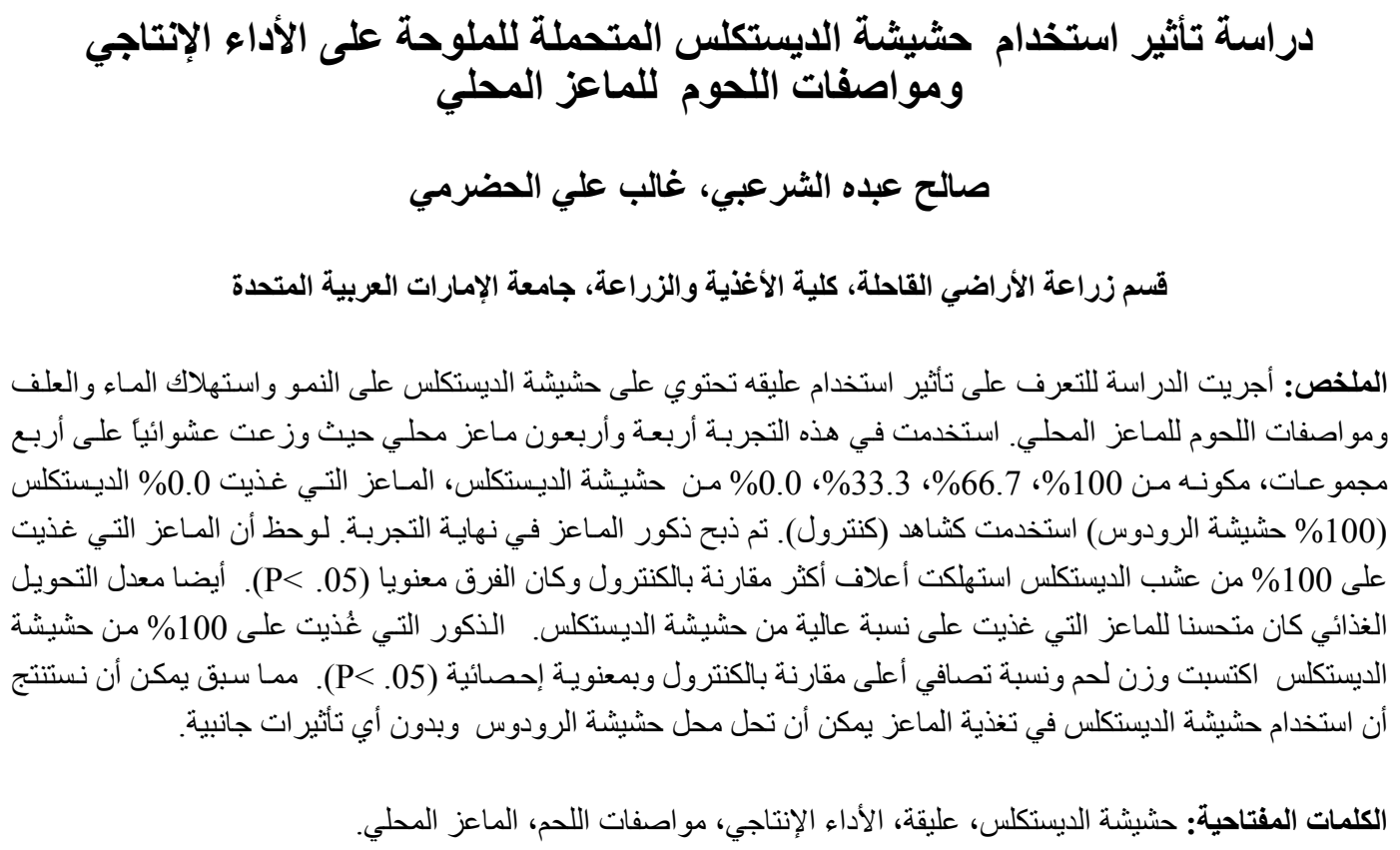

\section{Introduction}

Goats are an important meat producing animals in the United Arab Emirates (UAE). In 2005, there were 1.55 million goats out of 3 million livestock in UAE (Ministry of Environment and Water, 2005). The Emirati goat is the most common native breed in the UAE, constituting about $20 \%$ of the total goat 
population (Al-Shorepy et al., 2002). Goat meat is the more valued by local consumers over cattle, sheep and camel. Under traditional systems, goats make the best use of marginal grazing and browsing land, which covers most of the UAE. Under semi-intensive systems, goat production depends primarily on feeding Rhodes grass hay and concentrate, and, as a result, Rhodes grass production consumes nearly $50 \%$ of the total water used for agriculture in UAE, which has led to a reduction in groundwater levels, and, at the same time, caused drastic increases in the salinity of groundwaters. Thus, alternative sources of water and land on which to grow forage to feed the animals should be introduced. Salt-tolerant forage, especially grasses that grow well under saline conditions would be a potentially valuable alternative forage resource for grazing livestock, or as components of mixed rations. Such plants and grasses could play a major role in sustaining livestock production in UAE and many other countries (Gihad and El Shaer, 1994; Masters et al., 2007).

Recently, attention has been given to the possibility of growing halophytes as irrigated crops on a large scale (Glenn and Watson, 1993; Miyatmoto et al., 1994; Alhadrami et al., 2003; Al-Dakheel et al., 2006). Distichlis grass (Distichlis spicata), well known for its high salt tolerance, is grown as irrigated forage under high salinity condition in UAE (Lieth, 1994; Alhadrami et al, 1998; Alhadrami et al., 2003; Al-Dakheel et al., 2006). Unlike other salt-tolerant plants, which tend to accumulate a high content of salt in their leaves, Distichlis grass excludes salt from the roots (Gallagher, 1985), making this grass attractive an alternative forage for hay production in saline areas of the world. Research on the use of Distichlis grass hay as a livestock feed is limited. However, several studies conducted in UAE University to evaluate effects of feeding the salt-tolerant grass Sporobolus virginicus on performance of camels, sheep and goats (Alhadrami, 2003; Alhadrami et al., 2004; Al-Shorepy et al., 2005) found that animal performance was not influenced by the inclusion of various levels of this grass in their diets.

Since Distichlis grass is similar to Sporobolus grass, the same results may apply. Therefore, the objective of the present study was to assess effects of inclusion of Distichlis grass hay as a source of forage into whole-mixed diets on growth, feed and voluntary water intake and carcass composition of Emirati goat kids.

\section{Materials and Methods}

\section{Experimental animals, feeds and management}

The study was completed at the College of Food and Agriculture Experimental Station, UAE University, located in Al Foah area, $20 \mathrm{~km}$ north of Al Ain city. A total of 18 male and 26 female local goat kids (20 males, 22 females) were used in this study. Twenty-seven of these animals were born on the Experimental Station farm and the rest were purchased from local farmers. The kids were treated against internal and external parasites before commencement of the experiment.

The kids were randomly assigned within sex to four dietary treatments, which were formulated to have 100, 66.7, 33.3 or $0.0 \%$ Distichlis grass hay as the forage. The group receiving 0.0 Distichlis grass hay (100\% Rhodes grass hay) was the control. Distichlis grass was grown in saline desert lands and irrigated with groundwater of high salt content $(20,000$ ppm or more). After cutting, the Distichlis grass was sun dried until the moisture content reached about $15 \%$. The hay was baled into rectangular bales with an average weight of $11 \mathrm{~kg}$ per bale. Rhodes grass hay was obtained from local commercial sources. The chemical composition of both Rhodes grass and Distichilis grass is presented in Table 1 . The ration was mixed with chopped 
Distichlis grass hay and/or Rhodes grass hay to provide a ratio of 40:60 forage and concentrate respectively. The kids were fed in groups of the same sex. The composition and chemical analysis of the diets offered as a total a total of mixed ration are presented in Table 2 .

The kids were fed the experimental diets for an adaptation period of 7 days before the commencement of the experiment. The amount of feed offered each time to the goats was recorded daily. Refusals and wastage were weighed on the following morning. The total weight of the feed offered, adjusted for refusals and wastage, provided an estimate of the average feed consumed by each group per day throughout the study. The kids had free access to water and the volume of water offered each time was recorded daily and the remaining was recorded on the following morning. Daily water intake, corrected for losses, provided an estimate of the average water intake per day for each group. The kids were weighed individually on a weekly basis before feeding. Samples of feed were collected biweekly for chemical analyses (AOAC, 1990).

Table 1. Chemical composition of Rhodes and Distichlis grass (DM basis).

\begin{tabular}{lcc}
\hline & Rhodes grass & Distichlis grass \\
\hline Crude protein & 10.10 & 9.8 \\
Acid detergent fiber & 35.90 & 32.76 \\
Neutral detergent fiber & 73.21 & 74.08 \\
Ash & 10.70 & 11.53 \\
\hline
\end{tabular}

Table 2. Ingredient and chemical composition of the experimental diets.

\begin{tabular}{lcccc}
\hline & \multicolumn{4}{c}{ Treatment (\% Distichlis) } \\
\cline { 2 - 5 } Item & $\mathbf{0 . 0}$ & $\mathbf{3 3 . 3}$ & $\mathbf{6 6 . 7}$ & $\mathbf{1 0 0}$ \\
\hline Ingredient (\%) & & & \\
Distichlis grass hay & 0.0 & 13.6 & 26.4 & 40.0 \\
Rhodes grass hay & 40.0 & 26.4 & 13.6 & 0.0 \\
Barley grain & 38.0 & 38.0 & 38.0 & 38.0 \\
Wheat Bran & 10.0 & 10.0 & 10.0 & 10.0 \\
Soya Bean Meal & 10.0 & 10.0 & 10.0 & 10.0 \\
Di-Calcium & 1.0 & 1.0 & 1.0 & 1.0 \\
Vitamin and Minerals & 0.5 & 0.5 & 0.5 & 0.5 \\
Salt & 0.5 & 0.5 & 0.5 & 0.5 \\
Chemical composition (on DM Basis) & & & \\
Crude protein & 16.0 & 15.0 & 15.6 & 15.0 \\
Neutral detergent fiber & 46.2 & 46.0 & 47.8 & 49.8 \\
Acid detergent fiber & 18.7 & 16.3 & 17.7 & 18.9 \\
Ash & 9.8 & 9.8 & 8.6 & 8.6 \\
\hline
\end{tabular}




\section{Slaughtering Procedures}

At the end of a 70-day feeding period, the male goats (18) were slaughtered according to Islamic tradition whereby they were fasted for at least $12 \mathrm{~h}$, and body weight (BW) was recorded before slaughter. After slaughter, head, skin, feet and offal were removed and weighed. Full and empty reticulo-rumen were weighed and the weight of the gut content was calculated as the difference between full and empty weights. Empty body weight (EBW) was computed by subtracting the weight of digesta from live weight. The weights of other components of offal or non-carcass parts such as kidney and pelvic fat and different organs (liver, spleen, heart, kidneys, lung and trachea diaphragm and testes) were recorded. The weight of the non-carcass components was expressed in percentage of EBW. The dressing percentages were calculated as: dressing percentage $=$ carcass weight $/$ weight at slaughter; real dressing percentage $=$ carcass weight/EBW.

The carcass was then split longitudinally into two halves following the dorsal mid-line. From the left side, the 9th, 10th and 11th ribs were cut laterally to the vertebral column and parallel to the rib and subcutaneous fat thickness over $\mathrm{M}$. longissimus dorsi (LD) muscle was measured with a caliper. At the same point, the LD area was drawn on acetate paper and measured with a planimeter.

\section{Measurements}

The following measurements were recorded or calculated: average daily gain (ADG, g/day) was calculated as (final BW - initial BW / days on feed); dry matter intake (DMI, g/day) was calculated on a DM basis; feed conversion ratio (FCR) was calculated as DMI / weight gain; water consumption per unit feed intake $(1 / \mathrm{kg})$ was calculated as (TWI / DMI).

\section{Statistical Analysis}

Data were statistically analyzed using the General Linear Model procedures OF
SAS (1999). The linear model included effects of dietary treatment, sex of the lamb and the interaction between them in a $4 \times 2$ factorial design. A linear model that included only the effect of dietary treatment was used to analyze the slaughtering characteristics for the male goat kids. Differences among treatment means for significant dietary effect on growth and carcass parameters were analyzed using a least significant difference (LSD) method (Steel and Torrie, 1986). Significance was declared at $\mathrm{P}<0.05$.

\section{Results and Discussion}

\section{Feed and Water Intakes}

Feed and water intakes for the local male and female goats are in Table 3. The average daily feed intake per animal for both males and females was significantly higher $(\mathrm{P}<0.05)$ for the animals fed the diet containing 100\% Distichlis grass hay than those fed diets containing either 33.3 or $0.0 \%$ Distichlis grass hay. On the average, animals fed $100 \%$ Distichlis grass hay consumed $8 \%$ more than animals fed the control diet (100\% Rhodes grass hay). Also, the animals fed diets containing $66.7 \%$ Distichlis grass hay consumed more daily feed compared with those fed diets containing 33.3\% Distichlis grass hay. Daily water intake differed significantly (P $<0.05$ ) between the animals in diet containing $100 \%$ Distichlis grass hay compared to the control animals. These animals consumed on average $15 \%$ more water than the control animals did.

The goats in this study were able to increase their feed intake to compensate for the lower organic matter content of the Distichlis grass hay compared with Rhodes grass. In general, mean dry matter intake exceeded $3 \%$ of body weight for all treatment groups. This intake is within the range reported for Omani goats (El Hag and El Shargi, 1996; Mahgoub et al., 2005) and temperate goats ( $\mathrm{Lu}$ and Potchoiba, 
1990). Literatures on feeding Distichlis grass hay to goats are limited. However, similar results were reported by AlShorepy et al. (2004) for fattening lambs fed diets containing different levels of Sporobolus grass hay. Alhadrami et al. (2004) also reported higher feed intake for ewe lambs fed diet containing 100\% Sporobolus grass hay than for ewe lambs fed with Rhodes grass hay. Swingle et al. (1996) reported higher dry matter intake for lambs fed a diet containing halophyte forages than for lambs fed a control diet (Bermuda grass). It has been reported that supplementation of a low quality diet can improve intake in small ruminants such as sheep and goats (Getachew et al., 1994; Ondiek et al., 2005). Moreover, Al-Dabeeb (2005) concluded that when roughage of a low nitrogen concentration is given to ruminants, a supplementation with protein often results in an increase in voluntary feed intake, caused by increased availability of fermentable nitrogen. Voluntary water intake increased for goats fed diet containing 100\% Distichlis grass hay compared with those fed a controlled diet. The increased water consumption probably reflected the amount of $\mathrm{Na}$ in the diet containing halophyte Distichlis (Reffett and Boling, 1985). Swingle et al. (1996) found that lambs fed diets containing halophyte forages consumed up to $110 \%$ more water per day and $50 \%$ more water per kilogram of dry matter intake than those fed diets with Bermuda grass. Al-Shorepy, et al. (2004) reported that male and female lambs fed diets containing $100 \%$ Sporobolus grass hay consumed up to $121 \%$ more water per day than those fed the diets with Rhodes grass hay.

\section{Growth Rate and Feed Conversion}

The growth rate of the Emirati goat kids is presented in Table 4. Neither initial and final weights nor average daily gains of goats were significantly $(\mathrm{P}<0.05)$ affected by the diets. However, the goats fed diets containing Distichilis grass hay tended to gain weight faster than those in the control (100\% Rhodes grass hay), but the difference was not significant $(\mathrm{P}>0.05)$. The goats fed diets containing Distichis grass hay had better $(\mathrm{P}<0.05)$ feed conversion ratio (FCR) than the control goats ( $0 \%$ Distichis grass hay). Among the diets containing Distichis grass hay, the goats fed $66.7 \%$ Distichis grass hay had the lowest $((\mathrm{P}<0.05) \mathrm{FCR}$.

It is well known that faster growth rate may be mainly attributed to an increase in dry matter intake throughout the study period. Butterfield (1988) stated that animal growth rate, at a given age, is a function of food intake rather than time.

The daily weight gain of all groups in the current study was comparable with results reported by Marinova et al. (2001), Mahgoub et al. (2005), Sanon et al. (2008) for kids of similar age. Swingle et al. (1996) found that inclusion of the halophyte forages supported the same weight gain of lambs as cynodon hay and similar results were found in goats fed halophyte forages. Kraidees et al. (1998) reported that Najdi lambs fed with diets containing Salicornia stems tended to gain weight faster than those fed diets containing Rhodes grass hay. It was assumed that the body weight gain improvement might be related to increased body-water retention and accumulation of sodium (Masters et al., 2007; Kraidees et al., 1998). A lower feed conversion ratio, FCR, (kg feed/kg BW) was found for the animals fed various levels of Distichlis grass hay than the animals in the control group. Hence, the animals fed different levels of Distichlis grass hay tended to grow faster than the animals in the control group. The values of FCR obtained in the present study for animals fed different levels of Distichlis grass hay were lower than those reported for Dhofari goats in Oman. Mahgoub et al. (2005) reported a value of 11.3 for Dhofari goats fed high metabolizable energy diets. Also, an FCR value of 8.6 was reported by El Hag and El 
Shargi (1996) for Dhofari goats raised under a feedlot system. Similar FCR values were reported by Titi et al. (2007) for Shami goat kids.

Table 3. Least square means of feed and water intakes in Emirati goat kids fed different levels of Distichlis grass hay.

\begin{tabular}{lcccc}
\hline Distichlis \% & Sex & $\begin{array}{c}\text { Total feed } \\
\text { intake (Kg) }\end{array}$ & $\begin{array}{c}\text { Daily feed } \\
\text { intake (Kg) }\end{array}$ & $\begin{array}{c}\text { Daily water } \\
\text { intake (l) }\end{array}$ \\
\hline 0.0 & Male & $77.1^{\mathrm{b}}$ & $0.56^{\mathrm{b}}$ & $1.48^{\mathrm{b}}$ \\
33.4 & Male & $72.4^{\text {cd }}$ & $0.53^{\mathrm{cd}}$ & $1.41^{\mathrm{c}}$ \\
66.6 & Male & $74.0^{\mathrm{c}}$ & $0.54^{\mathrm{c}}$ & $1.04^{\mathrm{d}}$ \\
100 & Male & $82.0^{\mathrm{a}}$ & $0.61^{\mathrm{a}}$ & $1.73^{\mathrm{a}}$ \\
0.0 & Female & $62.4^{\mathrm{b}}$ & $0.46^{\mathrm{c}}$ & $1.02^{\mathrm{c}}$ \\
33.4 & Female & $65.5^{\mathrm{bc}}$ & $0.48^{\mathrm{b}}$ & $1.78^{\mathrm{a}}$ \\
66.6 & Female & $70.4^{\mathrm{a}}$ & $0.52^{\mathrm{c}}$ & $0.97^{\mathrm{cd}}$ \\
100 & Female & $68.8^{\mathrm{ac}}$ & $0.51^{\mathrm{a}}$ & $1.17^{\mathrm{b}}$ \\
Pooled SEM & & 1.022 & 0.007 & 0.03 \\
Main Effect & & & & \\
Diet type & $0.0 \%$ & $70.4^{\mathrm{bd}}$ & $0.51^{\mathrm{bc}}$ & $1.24^{\mathrm{c}}$ \\
& Distichlis & & & \\
& $33.4 \%$ & $69.0^{\mathrm{cd}}$ & $0.50^{\mathrm{b}}$ & $1.57^{\mathrm{a}}$ \\
& Distichlis & & & \\
& $66.6 \%$ & $72.2^{\mathrm{b}}$ & $0.53^{\mathrm{ac}}$ & $1.01^{\mathrm{d}}$ \\
& Distichlis & & & \\
Pooled SEM & $100 \%$ & $75.2^{\mathrm{a}}$ & $0.55^{\mathrm{a}}$ & $1.46^{\mathrm{b}}$ \\
Sex & Distichlis & & & \\
& & 1.12 & 0.008 & 0.04 \\
Pooled SEM & Male & $76.7^{\mathrm{a}}$ & $0.56^{\mathrm{a}}$ & $1.42^{\mathrm{a}}$ \\
Probabilities & Female & $66.8^{\mathrm{b}}$ & $0.49^{\mathrm{b}}$ & $1.24^{\mathrm{b}}$ \\
Diet type & & 0.74 & 0.006 & 0.05 \\
Sex & & & & \\
Diet type x Sex & & 0.001 & 0.001 & 0.001 \\
\hline & & 0.001 & 0.001 & 0.001 \\
\hline
\end{tabular}

Values in columns within each subcategory with different superscripts are significantly different $(\mathrm{P}<0.05)$.

\section{Body Composition}

The male goat kids fed various level of Distichlis grass hay and slaughtered at the end of the experiment had similar $(\mathrm{P}>$ $0.05)$ slaughter weights and empty body weights (EBW) (Table 5). However, hot carcass weights and dressing percentage for the animals fed diets containing 100\% Distichlis grass hay were significantly $(\mathrm{P}<$ $0.05)$ heavier than for the control animals. Expressed as \% of the EBW, there were no differences in non-carcass components between the goats fed different level of
Distichlis grass hay. The goats fed diet containing Distichis grass hay had lower $(\mathrm{P}<0.05)$ intestine-contents compared with those fed the control diet. There were only few significant effects of diet on the physical or chemical composition of the ribs (Table 5). The male goat kids fed a diet containing either 33.3 or $67.70 \%$ Distichis grass hay had lower $(\mathrm{P}<0.05)$ proportions of lean in the longissimus muscle (LD) than those fed a diet based on Rhodes grass hay. 
Table 4. Least square means of growth rate and feed efficiency in Emirati goat kids fed different levels of Distichlis grass hay.

\begin{tabular}{|c|c|c|c|c|c|}
\hline $\begin{array}{c}\text { Distichlis } \\
(\%)\end{array}$ & Sex & $\begin{array}{c}\text { Initial } \\
\text { Body } \\
\text { weight } \\
(\mathrm{Kg})\end{array}$ & $\begin{array}{c}\text { Final Body } \\
\text { weight } \\
\text { (Kg) }\end{array}$ & $\begin{array}{c}\text { Average } \\
\text { daily } \\
\text { gain (g) }\end{array}$ & $\begin{array}{c}\text { Daily feed } \\
\text { conversion } \\
\text { ratio }\end{array}$ \\
\hline 0.0 & Male & 12.56 & 17.71 & 74.08 & $10.44^{\mathrm{a}}$ \\
\hline 33.4 & Male & 11.64 & 17.33 & 82.38 & $8.17^{\mathrm{c}}$ \\
\hline 66.6 & Male & 13.14 & 18.93 & 83.93 & $7.56^{\mathrm{d}}$ \\
\hline 100 & Male & 13.49 & 19.35 & 84.92 & $9.22^{\mathrm{b}}$ \\
\hline 0.0 & Female & 11.91 & 14.43 & 36.51 & $8.30^{\mathrm{a}}$ \\
\hline 33.4 & Female & 12.31 & 16.01 & 53.55 & $7.39^{\mathrm{c}}$ \\
\hline 66.6 & Female & 9.77 & 14.31 & 65.82 & $7.19^{\mathrm{cd}}$ \\
\hline 100 & Female & 11.16 & 14.90 & 54.20 & $7.75^{\mathrm{b}}$ \\
\hline Pooled SEM & & 0.82 & 0.88 & 4.90 & 0.12 \\
\hline \multicolumn{6}{|l|}{ Main Effect } \\
\hline \multirow[t]{4}{*}{ Diet type } & $\begin{array}{c}0.0 \% \\
\text { Distichlis }\end{array}$ & 11.8 & 15.6 & 55.3 & $9.3^{\mathrm{a}}$ \\
\hline & $33.4 \%$ & 11.3 & 15.8 & 65.2 & $7.8^{\mathrm{c}}$ \\
\hline & $\begin{array}{c}\text { Distichlis } \\
66.6 \% \\
\text { Distichlis }\end{array}$ & 11.2 & 16.2 & 72.4 & $7.4^{\mathrm{d}}$ \\
\hline & $\begin{array}{c}100 \% \\
\text { Distichlis }\end{array}$ & 11.4 & 15.9 & 65.3 & $8.5^{\mathrm{b}}$ \\
\hline Pooled SEM & & 0.84 & 1.01 & 6.69 & 0.13 \\
\hline & Male & 12.1 & $17.6^{\mathrm{a}}$ & $79.6^{\mathrm{a}}$ & $8.8^{\mathrm{a}}$ \\
\hline & Female & 10.9 & $14.4^{\mathrm{b}}$ & $51.8^{\mathrm{b}}$ & $7.6^{\mathrm{b}}$ \\
\hline Pooled SEM & & 0.56 & 0.59 & 3.48 & 0.09 \\
\hline \multicolumn{6}{|l|}{ Probabilities } \\
\hline Diet type & & 0.94 & 0.97 & 0.83 & 0.001 \\
\hline Sex & & 0.15 & 0.001 & 0.001 & 0.001 \\
\hline Diet type x Sex & & 0.28 & 0.38 & 0.63 & 0.13 \\
\hline
\end{tabular}

Values in columns within each subcategory with different superscripts are significantly different $(\mathrm{P}<0.05)$.

Literature on the effects of feeding Distichlis grass hay on carcass characteristics is very limited. However, Swingle et al. (1996) concluded that inclusion of the halophyte forages did not effect the carcass merit of all experimental lambs. Kraidees et al. (1998) found that replacing Rhodes grass by Salicornia stems in the diet did not have an adverse effect on carcass characteristics of growing Najdi lambs if fresh water was available. AlShorepy et al. (2004) concluded that carcass characteristics of fattening indigenous lambs were not influenced by the inclusion of different levels of Sporobolus grass hay in the diets.

In general, the dressing percentage based on full live weight obtained in this study were higher than those obtained by Marichal, et al. (2003) for Canay Caprine goats in Spain and were similar to those obtained by Mahgoub et al. (2005) for Batina and Dhofari goats in Oman fed medium metabolizable energy diets.

In the absence of mineral composition data, it appears that the rate of passage of digesta may have accelerated in the goats fed diets containing different levels of Distichlis grass hay. This implied 
reduction of digesta-residue time in the rumen, which might have increased the dietary protein and soluble nutrients flow to the small intestine and resulted in increased absorption of nutrients of dietary origin and accounted for the lower feed conversion efficiency and higher gain. This is consistent with the findings of Kraidees et al. (1998) who reported a higher gain for lambs fed Salicornia stems than those in the control treatment. They further concluded that the changes in gain were presumably a direct consequence of the higher mineral intake on the Salicornia diets. Also, Kellaway et al. (1977) found that inclusion of $\mathrm{Na}$ up to $20 \mathrm{~g} \mathrm{~kg}^{-1} \mathrm{DM}$ was well tolerated by calves; the growth rate was $44 \%$ greater at $20 \mathrm{~g} \mathrm{Na} \mathrm{kg}^{-1} \mathrm{DM}$ compared to $2 \mathrm{~g} \mathrm{Na} \mathrm{kg}^{-1} \mathrm{DM}$. Moreover, Tomas et al.(1973) reported that in mixed hay and concentrate diets, increased dilution rate in the rumen enhanced the efficiency of microbial protein synthesis.

Table 5. Least squares means for carcass measurement and proportion of non-carcass components of Emirati goat kids fed different levels of Distichlis grass hay.

\begin{tabular}{|c|c|c|c|c|c|c|}
\hline & \multicolumn{4}{|c|}{ Treatment (\% Distichlis) } & \multirow{2}{*}{$\begin{array}{l}\text { Pooled } \\
\text { S.E.M }\end{array}$} & \multirow{2}{*}{$\mathbf{P}$} \\
\hline & $\mathbf{0 . 0}$ & 33.3 & 66.7 & 100 & & \\
\hline Slaughter weight $(\mathrm{kg})$ & 17.80 & 16.37 & 18.45 & 18.50 & 1.39 & 0.47 \\
\hline Empty body Weight $^{\mathrm{a}}(\mathrm{kg})$ & 15.31 & 14.23 & 16.16 & 15.98 & 1.23 & 0.72 \\
\hline Hot carcass weight $(\mathrm{kg})$ & 8.61 & 8.80 & 8.60 & 9.00 & 0.77 & 0.52 \\
\hline Hot dressing percentage $(\%)$ & $47.81^{\mathrm{b}}$ & $49.25^{\mathrm{ab}}$ & $48.20^{\mathrm{b}}$ & $50.20^{\mathrm{a}}$ & 0.92 & 0.04 \\
\hline \multicolumn{7}{|l|}{ Proportion (\%) on EBW ${ }^{b}$} \\
\hline Live weight & 116.42 & 115.04 & 114.77 & 115.76 & 1.25 & 0.77 \\
\hline Dressing & $57.24^{\mathrm{ab}}$ & $54.39^{\mathrm{c}}$ & $55.69^{\mathrm{bc}}$ & $58.56^{\mathrm{a}}$ & 0.78 & 0.02 \\
\hline Head & 9.09 & 8.68 & 8.65 & 8.82 & 0.39 & 0.81 \\
\hline Skin & 11.02 & 9.91 & 10.06 & 9.67 & 0.73 & 0.57 \\
\hline 4 feet & 3.68 & 3.54 & 3.56 & 3.70 & 0.15 & 0.82 \\
\hline Heart & 0.44 & 0.47 & 0.45 & 0.42 & 0.02 & 0.47 \\
\hline Heart fat & 0.20 & 0.18 & 0.17 & 0.19 & 0.02 & 0.90 \\
\hline Liver & 1.99 & 2.07 & 2.06 & 2.05 & 0.09 & 0.92 \\
\hline Lungs \& trachea & 1.33 & 1.35 & 1.40 & 1.32 & 0.08 & 0.90 \\
\hline Kidneys & 0.35 & 0.37 & 0.36 & 0.84 & 0.19 & 0.31 \\
\hline Spleen & 0.20 & 0.17 & 0.19 & 0.17 & 0.20 & 0.47 \\
\hline Testis & 0.71 & 0.82 & 0.70 & 0.73 & 0.09 & 0.78 \\
\hline GIT fat & 2.18 & 2.80 & 2.60 & 2.30 & 0.43 & 0.73 \\
\hline Rumen-contents & 11.70 & 11.90 & 12.20 & 11.85 & 1.09 & 0.70 \\
\hline Intestine-contents & $4.71^{\mathrm{a}}$ & $3.09^{c}$ & $2.56^{\mathrm{cd}}$ & $3.91^{\mathrm{b}}$ & 0.26 & 0.001 \\
\hline \multicolumn{7}{|l|}{ Physical dissection of rib cut: } \\
\hline Rib weight (gm) & 246.0 & 212.0 & 260.0 & 277.0 & 27.22 & 0.45 \\
\hline Rib Area (cm) & 9.08 & 8.11 & 8.13 & 8.42 & 0.69 & 0.72 \\
\hline Lean $(\%)$ & $62.55^{\mathrm{a}}$ & $55.25^{\mathrm{b}}$ & $56.55^{\mathrm{b}}$ & $59.96^{\mathrm{a}}$ & 1.98 & 0.08 \\
\hline Fat $(\%)$ & 11.44 & 15.25 & 13.25 & 12.58 & 1.99 & 0.60 \\
\hline Bone $(\%)$ & 18.77 & 21.21 & 22.63 & 21.52 & 1.45 & 0.29 \\
\hline \multicolumn{7}{|c|}{ Chemical composition of L. Dorsi muscle (\% DM): } \\
\hline Moisture & 72.71 & 71.56 & 72.19 & 70.61 & 0.76 & 0.29 \\
\hline Protein & 24.05 & 24.10 & 24.52 & 24.83 & 0.39 & 0.48 \\
\hline Ether Extract & 2.03 & 3.22 & 2.03 & 3.19 & 0.57 & 0.29 \\
\hline Ash & 1.01 & 0.94 & 1.07 & 0.99 & 0.03 & 0.06 \\
\hline
\end{tabular}

Values in rows with different superscripts are significantly different $(\mathrm{P}<0.05)$.

${ }^{\mathrm{a}}$ Whole empty body: live weight minus stomach and intestinal contents.

${ }^{b}$ The weight of an organ or tissue relative to that of the whole empty body weight as a percentage. 


\section{Conclusion}

These data suggest that inclusion of halophyte Distichlis grass hay up to $100 \%$ in the diet did not have an adverse effect on growth performance or carcass characteristics of growing Emirati goat kids.

\section{Acknowledgement}

This work was financially supported by the Research Affairs at the UAE University under contract no. 07-6-12/02. Special thanks are due to Adil El-Awad for his valuable assistance.

\section{References}

Al-Dabeeb, S. N. 2005. Effect of feeding low quality date palm on growth performance and apparent digestion coefficients in fattening Najdi sheep. Small Rumin. Res. 57:37-41.

Al-Dakheel, A. J., G. S. Al-Hadrami, S. A. Al-Shorepy and G. AbuRummani. 2006. Optimizing Management Practices for Maximum Production of Two Salt-Tolerant Grasses: Sporobolus virginicus and Distichlis spicata. Proc. Seventh Annual UAE University Res. Conf. 2. pp.44-50.

Alhadrami, G. A., M. H. Abdel-Gawad and J. Jumma.1998. In-Situ SM and fiber degradation in camels and In-Vitro gas production of two grasses irrigated with sea water. Third Annual Meeting for Animal Production under Arid Conditions, UAE University, United Arab Emirates.

Alhadrami, G. A. 2003. In situ dry matter and fiber degradation of salt tolerant Sporobolus grass hay in camels fed yeast culture. J. Camel Practice and Res. Vol. 10, No 2. pp.139-144.

Alhadrami, G. A., S. A. Al-Shorepy, M. A. Ayoub and A. M. Yousef. 2004. Growth performance of sheep fed
Sporobolus grass hay grown in saline desert lands and irrigated with high salt content water. Proc. Seventh Annual UAE University Res. Conf. pp. 27-34.

Al-Shorepy, S. A., G. A. Alhadrami and K. Abdulwahab. 2002. Genetic and phenotypic parameters for early growth traits in Emirati goats. Small Rumin. Res. 45:217-223.

Al-Shoropy, S.A., G. A. Alhadrami and A. J. Al-Dakheel. 2004. In: Proc. Sixth. Annual UAE University Res. Conf. 'Growth performance and body composition of indigenous sheep fed Sporobolus grass hay.' United Arab Emirates. 4. pp.45-50.

Ministry of Environment and Water. 2005. Agricultural census Results, Ministry of Environment and Water, Dubai, United Arab Emirates.

AOAC. 1990. Official Methods of Analysis, 15th ed. Association of Official Analytical Chemists, Arlington, VA.

Butterfield, R. M. 1988. New concepts of sheep growth. Department of Veterinary Anatomy. University of Sydney, Australia.

El Hag, M. G. and K. M. El Shargi. 1996. Feedlot performance and carcass characteristics of local (Dhofari) and exotic (Cashmere) goats fed on a highfiber by-products diet supplemented with fish sardine. Asian-Aust. J. Anim. Sci. 9:389-396.

Gallagher, J. 1985. Halophytic crops for cultivation at seawater salinity. Plant Soil. 89:323-336.

Getachew. G., A. N. Said and F. Sundstol. 1994. The effect of forage legume supplementation on digestibility and body weight gain by sheep fed a basal diet of maize stover. Anim. Feed Sci. Technol. 63:137-148. 
Gihad, E. A. and H. M. El Shaer.1994. Utilization of halophytes by livestock on rangelands: problems and prospects. In: V.R. Squires and A. T. Ayoub (Editors). Halophytes as a Resource for Livestock and for Rehabilitation of Degraded Lands. Kluwer Academic, Dordrceht. pp.77-96.

Kellaway, R. C., D. J. Thomson, D. E. Beever and D. F. Osbourn. 1977. Effects of $\mathrm{NaCl}$ growth rate and acid \pm base balance in calves. J. Agric. Sci., Camb. 88:1-9.

Kraidees, M. S., M. A. Abouheif, M. Y. Al-Saiady, A. Tag-Eldin and $\mathrm{H}$. Metwally. 1998. The effect of dietary inclusion of halophyte Salicornia bigelovii torr on growth performance and carcass characteristics of lambs. Anim. Feed Sci. Technol. 76:149-159.

Lieth, A. F. 1994. Use of sea water for growth and productivity of halophytes in the Gulf Region, M.S. Thesis, UAE University.

Lu, C. D. and M. J. Potchoiba.1990. Feed intake and weight gain of growing goats fed diets of various energy and protein levels. J. Anim. Sci. 68:1751-1759.

Mahgoub, O., C. D. Lu, M. S. Hameed, A.Richie, A. S. Al-Halhali and K.Annamalai. 2005. Performance of Omani goats fed diets containing various metabolizable energy densities. Small Rumin. Res. 58:175-180.

Marichal, A., N. Castro, J. Capote, M. J. Zamorano and A. Argüello. 2003. Effects of live weight at slaughter $(6,10$ and $25 \mathrm{~kg}$ ) on kid carcass and meat quality. Livest. Prod. Sci. 83:247-256.

Marinova, P., V. Bankalieva, V. Alexandrov, V. Tzvetkova and $\mathrm{H}$. Stanchev. 2001. Carcass composition and meat quality of kids fed sunflower oil supplemented diet. Small Rumin. Res. 42:219-227.
Masters, D. G., S. E. Benes and H. C. Norman. 2007. Biosaline agriculture for forage and livestock production. Agric., Ecos. Env. 119:234-248.

Ondiek, J. O., S. A. Abdulrazak, J. K. Tuitoek and F. B. Bareeba. 1999. The effects of Gliricidia sepium and maize bran as supplementary feed to Rhodes grass hay on intake, digestion and live weight of dairy goats. Livest. Prod. Sci. 61:65-70.

Reffett, J. K. and J. A. Boling. 1985. Nutrient utilization in lambs fed diets high in sodium or potassium. J. Anim. Sci. 61:1004-1009.

Sanon, H. O., C. Kaboré-Zoungrana and I. Ledin. 2008. Growth and carcass characteristics of male Sahelian goats fed leaves or pods of Pterocarpus lucens or Acacia senegal. Livest. Sci. In press.

SAS Institute Inc. 1990. SAS/STAT User's Guide version $6,4^{\text {th }}$ ed. SAS, Cary, NC, USA.

Steel, G. D. R., H. J. Torrie. 1986. Principles and Procedures of Statistics, 2nd. McGraw-Hill, New York, USA.

Swingle, R. S., E. P. Glenn and V. Squires. 1996. Growth performance of lambs fed mixed diets containing halophyte ingredients. Anim. Feed Sci. Technol. 63:137-148.

Titi, H. H., R. O. Dmoura, A. Y. Abdullahb. 2007. Growth performance and carcass characteristics of Awassi lambs and Shami goat kids fed yeast culture in their finishing diet. Anim. Feed Sci. Technol. In Press.

Tomas, F. M., G. B. Jones, B. J. Potter and G. L. Langsford. 1973. Influence of saline drinking water on mineral balances in sheep. Aust. J. Agric. Res. 24:377-386. 